\title{
Homenaje a äon Enrique Molina en el Congreso de Universidades
}

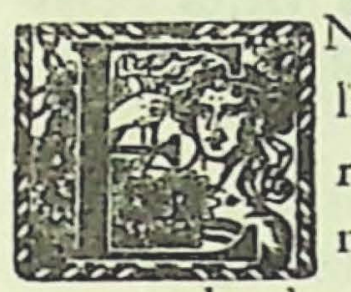

N UN ACTO que adquirió solemne e impresionante relieve y ante una concurrencia selecta en que estaba representada la cultura americana, en cuanto tiene de más elevada significación en las artes, en la enseñanza y en todas las manifestaciones del pensamiento, se le rindió homenaje de cariño y de respeto al eminente maestro don Enrique Molina. Hombre de clara estirpe espiritual, el señor Molina recibió este homenaje con la sobria sencillez que le caracteriza. Su calidad de más antiguo rector de las universidades de América y de creador de magníficas obras en pro de la cultura, aparte de su condición de escritor insigne, al abordar los temas de carácter filosófico, dieron con exceso motivo para que se le rindiera con cálido fervor este tributo de admiración.

Damos a continuación el texto de los discursos pronunciados en este acto de tan elevada alcurnia espiritual, por los señores Carlos Martínez Durán, Guillermo Feliú Cruz y Pedro Lira Urquieta.

Don Enrique Molina en feliz y brillante improvisación, agradeció poseído por intensa emoción, este homenaje que constituyó uno de los actos más señalados en el transcurso del Congreso de Universidades.

\section{DISCURSO DEL SR. CARLOS MARTINEZ DURAN}

Mucho me honra ser designado para ofrecer este homenaje al maestro y rector don Enrique Molina, cuya figura patriarcal es luz 
y superación en esta asamblea de universidades de nuestra América.

Don Enrique Molina ha consagrado sus ínclitas virtudes de pensamiento y corazón a educar muchas generaciones, y educar es la más alta misión del universitario americano. El se ha dado todo y desinteresadamente a la vida del espíritu. Múltiple en sus actividades generosas, uno en la armonía de sus saberes, es el más antiguo rector de las universidades latinoamericanas. En estos tiempos de destrucción y alteración en la jerarquía de los valores, es muy hermoso y saludable rendir admiración y veneración a los viejos maestros que siguen siendo tesoro del pensamiento universal, siempre renovado.

Cuando los años corren en tan rico acervo de verdad y belleza, cuánto gusto da acercarse a los que cargados de frutos ofrecen el milagro de una vejez a lo Séneca, íntegra y sabia, plena de las mejores esencias, siempre fluyendo en amor y sabiduría.

La estatua de don Enrique Molina es su propia vida y la Universidad de Concepción.

Don Enrique es una exhortación a vivir la vida en la forma más alta y noble, él es un evangelio vivo, porque sólo así se es maestro.

Vos, maestro, habéis escrito sobre Bergson. Con él os pedimos ese suplemento de alma necesaria para enfrentarse al progreso creciente de la ciencia.

Al rendiros homenaje os digo: felices los que llegan a las serenas cumbres sin mancha ni odio, felices los que hicieron su estatua, tallándola día tras día, a golpes de espíritu, con los eternos cinceles de la verdad, de la justicia y de la belleza.

\section{PALABRAS PRONUNCIADAS POR DON GUILLERMO FELIU CRUZ}

A medida que el juicio de la historia va enalteciendo las grandes figuras de nuestra enseñanza y se las ve engrandecerse como los forjadores de la nación, la figura de don Enrique Molina, hijo de la tradición de nuestra educación, se nos destaca muy nítidamente. 
Es un trozo, un pedazo de nuestra enseñanza.

En los días ya lejanos de la fundación del Instituto Pedagógico, fue don Enrique Molina alumno distinguido. En el largo bregar por la enseñanza, en el largo caminar suyo por el afán de formar generaciones, en el de ganar corazones y en el de que los corazones quieran, don Enrique ha sido maestro, apóstol, soldado, centinela de ideales.

En tan larga jornada, con una fe invencible en sí mismo, en el porvenir de su patria y en el de América, don Enrique Molina, el maestro ejemplar, fue cumpliendo su tarea. No hablemos ni del escritor ni del filósofo. Simplemente miremos al creador de espíritus. Pensad, señores, que todos vosotros sois maestros. Fijaos que cada uno de vosotros ha tenido la responsabilidad de las almas, no tanto para enseñar cosas cuanto para formar caracteres, ilusiones e ideales. Mirad en este hombre, en quien ya comienza la nieve a caer, tan lleno de vida y de ilusiones, tan fervorosamente destinado a forjar todavía los ideales, la encarnación del bien por el bien, de la sabiduría por la belleza.

Don Enrique Molina es por esto un ejemplo, pero ejemplos para que queden grabados en las mentes de los jóvenes necesitan también haber entregado algo más: la fe.

Nuestra juventud necesita fe, unida a una fuerte esperanza. Cuando comenzamos la obra, las objeciones hacen tambalear las ilusiones y a cada instante parece que el desaliento nos abrumara. En don Enrique Molina, el maestro, todo ha sido fe y por ello animador de almas. Ha sido también creador de cosas que existen y perdurarán por los siglos, mientras la raza, la ciencia, el arte y el espíritu vivan. Su obra es la Universidad de Concepción. Es su hija, su amor, su fe, su esperanza. Este maestro, que anduvo en los días juveniles formándose primero a sí mismo, cuando recién salió del Instituto Pedagógico, creó el hogar de la Universidad de Concepción y esa casa está irradiando en Chile y en América el fulgor de su ensueño de hombre. Este solo título le bastaría para hacer de su nombre un paradigma de la enseñanza. 
La Universidad de Chile, señores, al consagrarle este homenaje, siente que su figura une a los grandes maestros de esta casa y que su nombre significa ensueño para la juventud, belleza para nosotros y ejemplo para todos. Le ofrece también su respeto al más antiguo de los rectores universitarios del continente.

\section{DISCURSO DE DON PEDRO LIRA}

Hemos escuchado regocijados el elogio que ha tributado a don Enrique Molina el señor presidente de la Unión de Universidades Latinoamericanas. $\mathrm{Y}$ tomando pie de sus mismas palabras que celebran todo cuanto es caro al espíritu, intentaré en forma breve elogiar su obra, toda ella también impregnada de valores espirituales.

Hay en el sur de Chile una ciudad que en los tiempos lejanos de la Colonia y en tiempos heroicos de la República, fue el baluarte militar del país. Allí, en Concepción, comenzaba la Frontera y hasta sus aledaños llegaron las impetuosas acometidas de los araucanos. Pues bien, esa bella ciudad, que siempre había sido considerada como sede auténtica de Marté - si se me permite usar el pomposo vocabulario de antiguas fiestas académicas-, se ha visto en nuestros días transformada en sede de Atenea y ello por el esfuerzo de don Enrique Molina.

Porque en esto reside, justamente, el elemento esencial que da relieve a su simpática figura: en que le fue dado recoger una idea audaz y fecunda, auspiciarla, acariciarla, darle vida, y lo que es más sorprendente, verla vivir y crecer en armonía con ella, sin jamás abandonarla ni ser abandonado. Desde hace treinta años la Universidad de Concepción es parte principalísima de la existencia de don Enrique Molina, y su verbo y su acción son a la vez partę principalísima de la existencia universitaria.

La ha amado con amor visceral. Le ha dado cuanto ha tenido y que no ha sido poco porque este varón de muchos saberes le ha entregado a la Universidad la claridad de su mente y el fervor de su voluntad, su generosa tolerancia y su invencible esperanza. Por 
eso ha crecido y ha prosperado una obra inmensa que por muchos títulos es nacional. Nacida de la iniciativa privada, fortalecida con el apoyo de la región, se ha extendido por el país entero y por la América nuestra. ¿Cómo silenciar el encomio que merece el hombre que la ha hecho? ¿Cómo no enaltecer a quien ha perseverado en su tarea creyendo en la eficacia de la verdad?

Podría decir de don Enrique Molina, con frase de clásico, que tiene claro y manso ingenio, aspecto señorial y ánimo constante para grandes hechos. Agregaría que nunca ha transitado por veredas sombrías ni por sendas tortuosas porque en su pecho no han anidado las ruines aves de la envidia, de la desconfianza y del odio. Por esta causa, más afortunado que muchos ha visto su trabajo celebrado por todos. Y a semejanza del gran Bello, llega al arrabal de la senectud, como dijo el poeta de las Coplas, con mente ágil y con corazón enardecido.

En nombre de los universitarios chilenos, de las universidades particulares y en especial de la Universidad Católica de Chile, rindo gustoso este homenaje cordial a don Enrique Molina y pido a Dios que continúe conservándolo y protegiéndolo para prez de nues. tra patria y de nuestra raza. 